\title{
A Study on the Application of National Competency Standards (NCS) to 4-year Universities in South Korea-Focused on the Case of K-Univ. -
}

\author{
Su-Won Kim \\ Korea Research Institute for Vocational Education and Training, Sejong-si, South Korea \\ Kyu-Suk Chung \\ Kangwon National University, Gangwon, South Korea
}

\begin{abstract}
In South Korea, the vocational education and training institutions, such as the vocational colleges, the vocational high schools, and the vocational training institutions is applying the National Competency Standards (NCS). NCS is function as a key link in development of the human resource development (HRD), linking work, education and training, and qualifications by analyzing and presenting systematically the job demands of the industrial field. The 4-year universities that focus generally on the theoretical studies do not yet have applied NCS in South Korea. However, in the case of 4-year universities, the importance of professional education is emphasized by being derived and independed from more precise the individual science through the advancement of science and technology, and the division of social functions. Therefore, it is desirable to apply NCS to improve the practical expertise of 4-year university students. For this purpose, this study aims to compare the curriculum of national K-University and the NCS contents, and to find out how to apply it to the curriculum of 4-year universities in order to bring about the functions and the characteristics of education and training.
\end{abstract}

Keywords: National Competency Standards (NCS), 4-year universities, curriculum, application

\section{Introduction}

The National Competency Standards (NCS) is that the country is systematized the contents of knowledge, skills, and attitudes required to perform the duty at the industrial field according to the industry sector and the level (Article 2(2) of the "the Basic Act on Qualifications"). NCS is function as a key link between work, education and training, and qualifications, that is, core of the human resource development (HRD). It is believed that the development of curriculum through NCS is meaningful in that it can make use of the functions and the characteristics of education and training.

NCS consists of the systems for development and operation of NCS and the outputs developed under this system. Namely, it can be classified into contents, such as the development and the utilization of NCS, the infrastructure of management and operation, the job system, the NCS, the curriculum of education and training, and the textbook.

Su-Won Kim, Ph.D. in Business Administration, Korea Research Institute for Vocational Education and Training.

Kyu-Suk Chung, Ph.D. in Business Administration, Division of Business Administration \& Accounting, Kangwon National University. 
In South Korea, the vocational education and training institutions, such as the vocational colleges, the vocational high schools, and the vocational training institutions is applying NCS. However, the general 4-year universities are passive in introducing $N C S$, because it is an academic-oriented educational institution that is the theoretical discipline.

However, in the case of 4-year universities, the importance of professional education is emphasized as the advancement of science and technology, and the division of social functions. In addition, it is desirable to apply NCS in order to improve the professionalism of 4-year universities students' field work. Namely, it is desirable to apply NCS to 4-year universities and to activate opportunities to discover and share the using cases of NCS in order to develop the lifelong career that links high school-university field.

Therefore, there is a need to encourage the PR and the utilization of 4-year universities to operate the curriculum based on contents suitable for the undergraduate level. In particular, it is necessary to operate the NCS-based curriculum that reflects the needs of the general high schools and the vocational high schools in career development in order to become a center for transition of the ability-based society at 4-year universities.

In this paper, we compared the NCS contents with the education curriculum of K-University's Business School, which is the national university of Korea. And it explored some schemes applying NCS to the education contents of 4-year universities.

\section{Status of the Development and Application System of NCS}

NCS have the purpose to link the work, the education, training, and the qualifications, and to transform the vocational education and training, and the qualification system into center of the job performance capacity.

$N C S$ develops through the analysis of job and industry of the industry and the labor market, and applies it to the education and training curriculum of the education and the job training, and utilizes it to build the ability-based recruitment system of the industry and the labor market.

\section{Status of the Development System of NCS}

$N C S$ is mainly developed by the Ministry of Employment and Labor, and the human resources development service of Korea. In practice, it is developed by industrial personnel, educational personnel, and qualification experts by each job.

The classification of NCS is shown a step-by-step configuration, focusing on the type of job and it presents the overall roadmap of NCS development. NCS is composed of major category (24), middle category (77), small category (227), and subdivision (857).

The duty refers to subdivision at the classification system of NCS. In principle, standards are developed in the subdivision. The competency unit is sub-units of the classification system of NCS and corresponds to the basic components of NCS. The competency unit consists of competency unit code, competency unit name, competency unit definition, competency unit element (e.g., performance criteria, knowledge, skills, and attitudes), coverage and working condition, evaluation guideline, and vocational basic ability.

The level system of NCS systematizes the level of job in the industrial field. It is used in connection with work, education and training, and qualifications, presentation of the achievement level of lifelong learning, and composition of the level system of qualification. When it develops NCS, it is presented by evaluating the levels of competency unit and competency unit element according to the level system of eight levels (minimum Level 1 to maximum Level 8). 
Table 1

The Classification System of NCS

\begin{tabular}{|c|c|c|c|}
\hline Main category & Middle category & Small category & Subdivision \\
\hline 1. Business Management & 1 & 1 & 3 \\
\hline 2. Management·Accounting·Office Work & 4 & 11 & 25 \\
\hline 3. Finance-Insurance & 2 & 9 & 35 \\
\hline 4. Education-Nature-Social Science & 3 & 5 & 13 \\
\hline 5. Law·Police·Fire $\cdot$ Corps $\cdot$ Defense & 2 & 4 & 15 \\
\hline 6. Health·Medical Care & 2 & 7 & 33 \\
\hline 7. Social Welfare·Religion & 1 & 5 & 13 \\
\hline 8. Culture $\cdot$ Art $\cdot$ Design $\cdot$ Broadcasting & 3 & 9 & 62 \\
\hline 9. Driving $\cdot$ Transportation & 4 & 7 & 26 \\
\hline 10. Business·Sales & 3 & 7 & 17 \\
\hline 11. Guard·Cleaning & 2 & 3 & 6 \\
\hline 12. Hairdressing $\cdot$ Accommodation $\cdot$ Travel-Entertainment $\cdot$ Sports & 4 & 12 & 42 \\
\hline 13. Food Service & 1 & 2 & 8 \\
\hline 14. Construction & 8 & 24 & 102 \\
\hline 15. Machine & 9 & 27 & 113 \\
\hline 16. Materials & 2 & 7 & 34 \\
\hline 17. Chemistry & 4 & 10 & 31 \\
\hline 18. Textiles·Clothing & 2 & 7 & 22 \\
\hline 19. Electricity·Electronics & 3 & 22 & 67 \\
\hline 20. Information Communication & 3 & 11 & 57 \\
\hline 21. Food Processing & 2 & 4 & 20 \\
\hline 22. Printing $\cdot$ Wood $\cdot$ Furniture $\cdot$ Crafts & 2 & 4 & 23 \\
\hline 23. Environment·Energy·Safety & 6 & 17 & 48 \\
\hline 24. Agriculture·Forestry Fishing & 4 & 12 & 42 \\
\hline Total & 77 & 227 & 857 \\
\hline
\end{tabular}

Note. Source: National Competency Standards website (see http://www.ncs.go.kr) (Aug. 2014).

The utilization package of NCS is the contents that can be used in work, education and training, and qualifications field by using $N C S$, and aims to improve the utilization through making easily the uses of $N C S$ for each field, thereby. These utilization packages consist of the paths of lifelong career development (job description, recruitment and placement, promotion checklist, and self-diagnostic tool), the training standards, and the question standards.

\section{Status of the Application System of NCS}

In order to strengthen the linkage of work, education and training, and qualifications, the government is doing the efforts to develop/operate the curriculums of education and training, and to disseminate the manuals through utilizing NCS. The Ministry of Education revised the curriculum of the vocational high school based on NCS from 2013, and announced it as the "2015 revised curriculums" in September 2015. The vocational colleges suggested the reform of NCS-based curriculum as a basic requirement of financial support project in 2014, and developed and distributed the manuals to support the development of NCS-based curriculum at vocational colleges in 2015. The Ministry of Employment and Labor has improved as the training standards based on NCS from 2013 and is supporting on the premise of NCS-based training for all the training institutions and the polytechnics operating the training programs. In the second half of 2013, it was introduced the 
work-learning parallel system as a Korean-style - the education and training system of apprenticeship (see Figure 1).

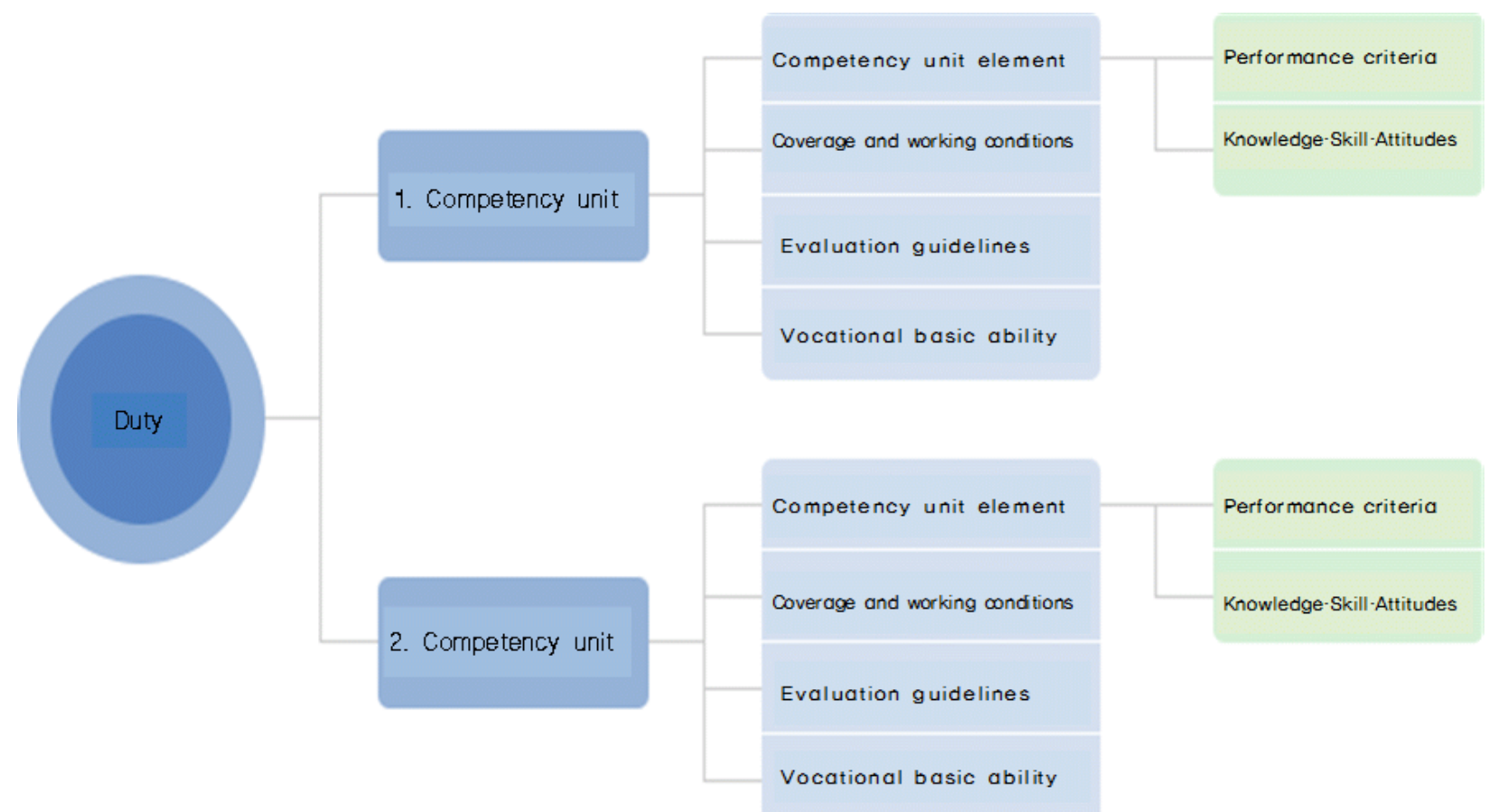

Figure 1. Composition for the competency unit of NCS. Source: NCS homepage (see http://www.ncs.go.kr/) in November 10, 2017.

The Ministry of Education has developed an NCS-based learning module as part of its efforts to apply NCS. The NCS-based learning module is a detailed description of the contents related to theories, knowledge, and practices learning the specific tasks based on NCS in the field (Ministry of Education, 2016). The NCS-based learning module is intended to be used as a basic teaching and learning material in the vocational educational and training institutions, and to be used in the reform of curriculum. As for the development status of NCS-based learning modules, 772 kinds based on subdivision of NCS has been developed since 2013 (see Figure 2).

The government will establish a job-centered education system through the introduction of NCS as a medium linking work, education and training, and qualifications, and promote the reform of the qualifications system to secure the field and the communication of qualifications and the linkage of work, education and training, and qualifications. The Ministry of Employment and Labor promoted specifically the reform of NCS-based qualifications from 2013 to 2015.

1. It had revised the national technical qualifications of 431 through applying the NCS to the questions standards and the evaluation methods of the national technical qualifications until 2015. The evaluation method of the practical test has been improved in various forms (e.g., work type $\rightarrow$ work creation, drawing design, simulation) in order to conform to NCS and the industrial field.

2. The national technical qualification is redesigned as a new vocational qualification, which is designed as NCS-based on the qualification items (prototype) needed in the industrial field in order to be used for the reorganization, abolition, conversion, integration, etc. The new vocational qualification system is designed a 
qualification system that can be used in the relevant industry through linking the relevant NCS with the qualification items and the path of career development is presented by basing on this. The new vocational qualification was completed for 600 qualifications in 24 fields until 2015.

3. It has reformed the formulas acquiring the qualifications as the qualification system of course evaluation type from 2015. The qualification system of course evaluation type is a system that acquires the national technical qualification through systematic completion of designated the NCS-based education and training courses and the internal/external evaluation. This system applied 15 items in the machinery and molds field at first in 2015 and will be expanded gradually.

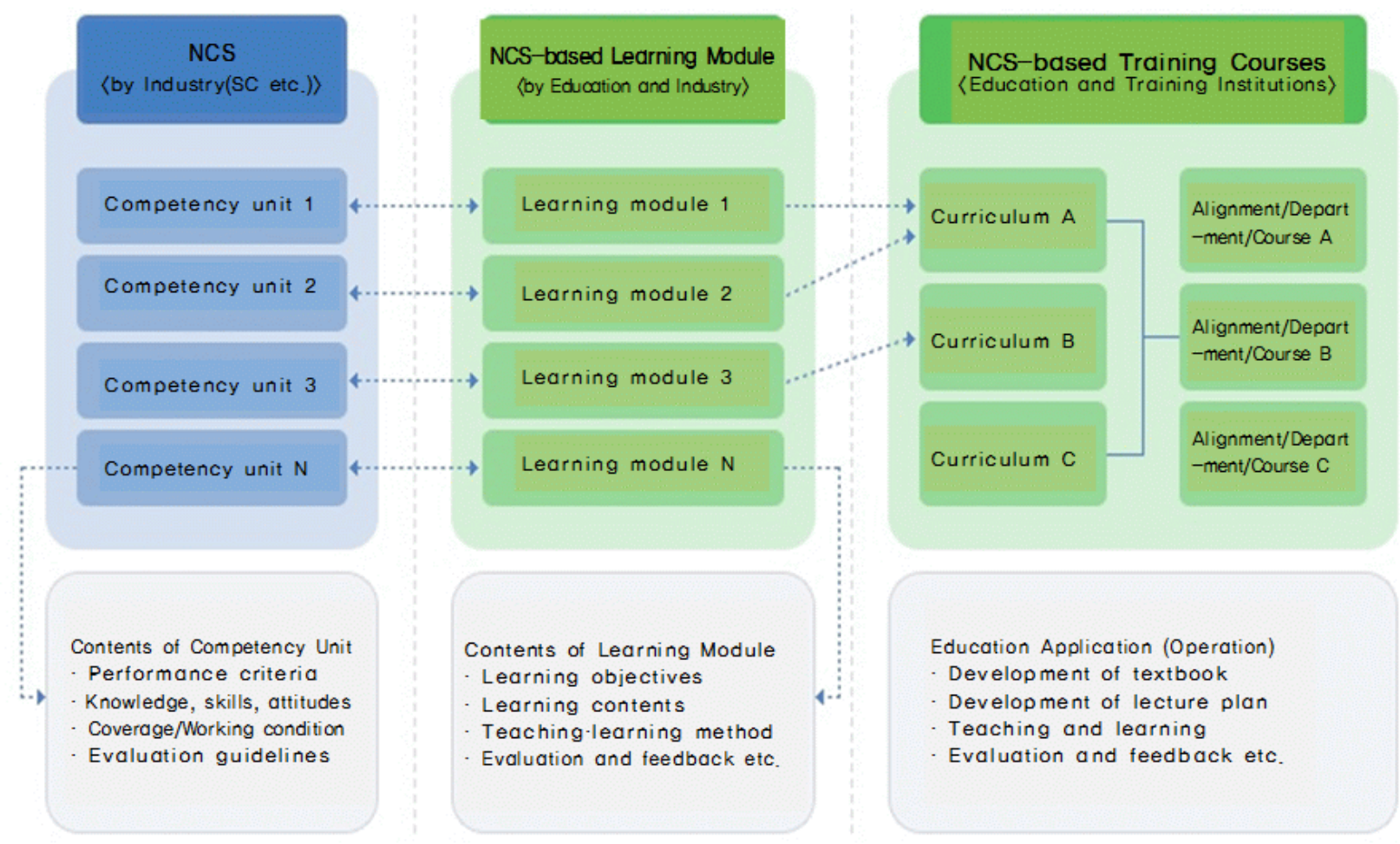

Figure 2. Concepts and features of NCS-based learning module. Source: NCS website (see http://www.ncs.go.kr) in August, 2014.

The government will build a NCS-based National Qualifications Framework (NQF) that links the equivalence of degrees, qualifications, experiences, and careers. NQF is a nation accreditation standard for systematic recognition of school education, vocational training, qualifications, field careers, etc. based on NCS.

The government is promoting the introduction of the NCS-based job competency evaluation system for building a competency-centered recruitment system as the last step of establishing the NCS system. The NCS-based competency-centered recruitment is to verify the competency elements of the actual viewpoints required by the job in the recruitment procedure. It specifies the recruitment requirements, and emphasizes the job basic ability and the job performance ability to do work. In order to spread the NCS-based competency-centered recruitment system, the Ministry of Employment and Labor carried out the consulting support for the public institution of 135 in 2015, and promoted the consulting for the private companies of 890 , and expanded the education to improve the understanding for the job preparation person and the HR managers (Human Resources Development Service of Korea, 2015). 


\section{Introduction and Operation Status of $N C S$ and its Problems at K-University Focusing on the Curriculum of Business School}

\section{Introduction and Operation of NCS, and Future Plans}

In order to strengthen students' the employment competitiveness and their basic competencies for lifelong career, the individual colleges (or department) are trying to review and reflect NCS in the curriculum from 2015.

In K-University's Business School, it reorganizes the major course based on NCS, uses the question for ability-centered recruitment based the related NCS by class, and supports the classes preparing NCS (e.g., learning clubs, etc.) (Kangwon University's School of Management and Accountancy, 2016). The results of NCS-related interviews with the faculty members in Business School, such as some professors and the office assistants are as the following:

1. Most of professors and staff do not feel the need for introduction of NCS. But some professors interest in the utilization of NCS for the purpose of supporting the employment of students' public institutions and large companies.

2. Most of professors and staff understand the basics, such as the concept of NCS. But they lack the in-depth knowledge, such as how to apply the curriculum and how to evaluate the job performance of NCS.

3. The introduction of NCS takes place partly on the individual level of professors. For example, it describes NCS-related fields in the lesson plan by each subject, and delivers this to students

4. Students are expected to learn and improve their basic skills, how to write a self-introduction letter, and interview tips as part of their job preparation. In this respect, it is supporting the operation in the form of the (non-curriculum) liberal arts education, such as the learning clubs and the special lectures. However, the related learning clubs are around 10 and the number of participating students is less than $30 \%$ of the total students.

5. College of Engineering at S-Campus has introduced the long-term field practice of Industry Professional Practice (IPP)-type ${ }^{1}$ and the work-learning parallel system ${ }^{2}$ which reflects NCS-based education and training for the purpose of field practice and employment support of students from 2015.

\section{Comparison of Business School's Curriculum and the Classification System Related NCS}

There are Business Administration, Accounting, Economics, International Trade, Tourism Management, and Global Business within the Business School. The major subjects related to NCS of management, accounting, and taxation are Business Administration, Economics, and International Trade. Tourism Management and Global Business are related to some of NCS (see Table 2).

NCS of management, accounting, and taxation divided into Management Planning, PR and Advertising, Marketing, General Affairs, Personnel and Organization, Financial Affairs, Accounting, Production Management, Quality Management, Distribution Management, etc. in the small category. NCS of finance and insurance is divided Finance and Insurance in the middle category. NCS that is related to the major of Business School at K-University are Management Planning, Marketing, Personnel and Organization, Financial Affairs, Accounting, Production Management, Quality Control, and Distribution Management and Finance, but Publicity, Advertisement, General Affairs, Insurance, etc. is excluded (see Table 3).

\footnotetext{
${ }^{1}$ IPP is a long-term field practice system that allows a part of the university's curriculum to be taken on an industrial field for a long period of time (four months to 10 months). And it is an industry-university cooperative education model that integrates academic semester reflecting the latest industry trends and company's needs and practice semester of the industrial field related to major.

2 The work-learning parallel system is an apprenticeship training system designed to suit the apprenticeship system of German and Swiss in Korea in order to nurture the practitioners in the industrial field.
} 
Table 2

Curriculum of K-University's Business School

\begin{tabular}{|l|l|l|l|}
\hline College & Undergraduate & Major & Details of major \\
\hline & $\begin{array}{l}\text { Faculty of } \\
\text { Management and } \\
\text { Accounting }\end{array}$ & Major in Management & $\begin{array}{l}\text { Personnel Management, Production Management, Marketing, } \\
\text { Financial Management, etc. }\end{array}$ \\
\cline { 2 - 3 } & Major in Accounting & $\begin{array}{l}\text { Financial Accounting, Management Accounting, Taxation, } \\
\text { Accounting, Accounting Information System, Accounting } \\
\text { Audit, Non-profit Accounting, International Accounting, etc. }\end{array}$ \\
\cline { 2 - 4 } $\begin{array}{l}\text { College of } \\
\text { Business } \\
\text { Administration }\end{array}$ & $\begin{array}{l}\text { Faculty of } \\
\text { Economics and } \\
\text { Trade }\end{array}$ & Major in Economics & $\begin{array}{l}\text { Macroeconomics, Microeconomics, Economic Mathematics, } \\
\text { Econometrics, International Economics, Monetary Finance, } \\
\text { Finance, Industrial Organization, Labor Economics, } \\
\text { Environmental Economics, etc. }\end{array}$ \\
\cline { 2 - 3 } & Major in International Trade & $\begin{array}{l}\text { International Economics, International Business, International } \\
\text { Business, etc. }\end{array}$ \\
\cline { 2 - 3 } & $\begin{array}{l}\text { Hotel Management, Tourism Marketing, Leisure } \\
\text { Management, Tourism Economy, Tourism Development, etc. }\end{array}$ \\
\cline { 2 - 3 } & Department of Tourism Management & $\begin{array}{l}\text { Global Business Talent Tracking Track, Global } \\
\text { Accounting .Financial Specialist Training Track, Global Data } \\
\text { Scientist Talent Track, etc. }\end{array}$ \\
\hline
\end{tabular}

Table 3

NCS Classification System in Management, Accounting, Taxation, Finance and Insurance

\begin{tabular}{|c|c|c|c|}
\hline Main category & Middle category & Small category & Subdivision \\
\hline \multirow{10}{*}{$\begin{array}{l}\text { Management, } \\
\text { Accounting, } \\
\text { Taxation }\end{array}$} & \multirow[b]{3}{*}{ Planning Office } & Management Planning & Management Plan, Management Evaluation \\
\hline & & PR \& Advertising & Corporate Promotion, PR/Advertising \\
\hline & & Marketing & $\begin{array}{l}\text { Marketing Strategy Planning, Customer Management, Inquiry } \\
\text { Survey }\end{array}$ \\
\hline & \multirow{2}{*}{$\begin{array}{l}\text { General Affairs \& } \\
\text { Personnel }\end{array}$} & General Affairs & General Affairs, Asset Management, Emergency Planning \\
\hline & & Personnel \& Organization & Personnel, Work Management \\
\hline & \multirow{2}{*}{$\begin{array}{l}\text { Financial Affairs \& } \\
\text { Accounting }\end{array}$} & Financial Affairs & Budget, Funds \\
\hline & & Accounting & Accounting \& Auditing, Taxation \\
\hline & \multirow{3}{*}{$\begin{array}{l}\text { Production \& } \\
\text { Quality } \\
\text { Management }\end{array}$} & Production Management & $\begin{array}{l}\text { Purchase Procurement, Material Management, Process } \\
\text { Management, SCM }\end{array}$ \\
\hline & & Quality Management & QM/QC Management \\
\hline & & Distribution Management & Distribution Management, Export \& Import Management \\
\hline \multirow{6}{*}{$\begin{array}{l}\text { Finance \& } \\
\text { Insurance }\end{array}$} & \multirow{6}{*}{ Finance } & Financial Business & $\begin{array}{l}\text { Charging Office, Corporate Business, PB Business, } \\
\text { Card Business }\end{array}$ \\
\hline & & $\begin{array}{l}\text { Development of Financial } \\
\text { Products }\end{array}$ & $\begin{array}{l}\text { Developed Credit and Reception Product, Developed } \\
\text { Investment Product, Developed Pension Product, } \\
\text { Developed Card Product }\end{array}$ \\
\hline & & Credit Analysis & $\begin{array}{l}\text { Personal Credit Analysis, Corporate Credit Analysis, } \\
\text { Exchange Bill Processing }\end{array}$ \\
\hline & & Asset Management & $\begin{array}{l}\text { Fund Management, Bond and Securities Management, } \\
\text { Derivative Product Management, Alternative Investment, } \\
\text { Trust Investment Management }\end{array}$ \\
\hline & & Financial Sales Support & Payment, Collection of Credits, Risk Management \\
\hline & & $\begin{array}{l}\text { Security \& Foreign } \\
\text { Exchange }\end{array}$ & $\begin{array}{l}\text { Increase Transaction Business, Foreign Exchange Derivative } \\
\text { Business, Acquisition Business, Listing of Related } \\
\text { Institutions, Registration and Abolition Work, } \\
\text { Foreign Capital Procurement, Foreign Currency Lending } \\
\text { Business, Trade Finance Business }\end{array}$ \\
\hline
\end{tabular}


(Table 3 to be continued)

\begin{tabular}{|l|l|l|l|}
\hline \multirow{2}{*}{$\begin{array}{l}\text { Finance \& } \\
\text { Insurance }\end{array}$} & \multirow{2}{*}{ Insurance } & $\begin{array}{l}\text { Insurance Product } \\
\text { Development }\end{array}$ & $\begin{array}{l}\text { Analysis of Insurance Trends, Development of Insurance } \\
\text { Products, Actuaries }\end{array}$ \\
\cline { 3 - 4 } & Insurance Sales Contract & $\begin{array}{l}\text { Insurance Subscription, Insurance Review, Insurance } \\
\text { Contract, Maintenance, Risk Management }\end{array}$ \\
\cline { 2 - 3 } & No Damages & $\begin{array}{l}\text { Fire Specific Insurance Damage Assessment, Marine Insurance } \\
\text { Damage Assessment, Auto Insurance Damage Assessment }\end{array}$ \\
\hline
\end{tabular}

\section{Comparison of Business School's Curriculum and the Details Related NCS}

The results of comparing the curriculum of Business School and the competency units of NCS at Production Management, Quality Management, and Personnel Management are as follows: The ratios of NCS contents among the parts that can be applied and the parts that cannot be applied to Business School's textbooks are $2: 3$ for Production Management, $4: 3$ for Quality Management, and $4: 3$ for Personnel Management.

In the curriculum of Production Management, the possible parts to apply are as follows: Production strategy, Total Quality Management (TQM), part of "Design and improvement of process," part of "Arrangement of facilities and equipment," part of "Design and measurement of work," part of "Schedule management of the project," part of "Production planning," Material and inventory management, part of "Inventory management of subsidiary demand products: MRP system," and Equipment maintenance.

In the curriculum of Quality Management, the possible parts to apply are as follows: part of "Standardization and internal standardization," Design of customer satisfaction quality, part of "Design of quality system," part of "Statistical quality control," Sampling inspection, Quality assurance of products, Quality assurance by certification of quality system (International Standardization Organization [ISO] 9000 series), Quality assurance of outsourced products (outsourcing quality management), part of "Reliability management," Quality improvement of products, Analysis and improvement of process capability, Quality management with participation, Quality information system, part of "Measurement, analysis and improvement of quality cost," and Management of service quality.

In the curriculum of human resource management (personnel management), the possible parts to apply are as follows: part of "Start of implementation of human resource management," part of "Start of human resource management: Job management," Recruitment of human resources, Nurturing and development of human resources, Management of promotion and movement. Turnover, Evaluation of achievements, Wage management, part of "Welfare and industrial safety," human resource management for improvement of labor-manager relations, and human resource management through corporate culture.

The reasons for discrepancy between the curriculum of Business School and the competency units of NCS are as follows.

1. It is difficult to apply because the textbook is mainly in theory;

2. There is no NCS corresponding to the contents of textbook;

3. It is difficult to apply because the job level of NCS is low level of two to three steps;

\section{Applying NCS at 4-Year Universities in Korea}

\section{Application of NCS According to Purpose}

It clarifies the purpose of the university's educational goals and the purpose of using NCS, and determines the type of application and its scope according to the NCS utilization target (e.g., promotion project, target demand-layer, etc.). 
The method of using NCS-based curriculum of 4-year universities can be classified into three categories (department-applied, employment-supported, and individual-applied) and nine types (subject-application of school level, subject-application based on department, establishment of the contract department, linked to specialization business, cultivating of the vocational basic ability, utilization of non-curriculum, internship field practice, subject-application of professor level, and utilization of research meeting/small group) according to the purpose of uses (see Table 4).

Table 4

Types and Status of NCS at 4-Year Universities

\begin{tabular}{|c|c|c|}
\hline Classification & Type & Contents \\
\hline \multirow{4}{*}{ Department -applied } & Subject-application of school level & $\begin{array}{l}\text { Focus on establishing and operating the NCS-based curriculum } \\
\text { at school level }\end{array}$ \\
\hline & Subject-application based on department & $\begin{array}{l}\text { Focus on establishing and operating the } N C S \text {-based curriculum } \\
\text { at department level }\end{array}$ \\
\hline & Establishment of the contract department & $\begin{array}{l}\text { Operating the curriculum through applying } N C S \text { to established } \\
\text { (scheduled) the contract department }\end{array}$ \\
\hline & Linked to specialization business & $\begin{array}{l}\text { (As part of the government funding project) Plan and conduct } \\
\text { the specialization projects using NCS }\end{array}$ \\
\hline \multirow{3}{*}{$\begin{array}{l}\text { Employment } \\
\text {-supported }\end{array}$} & Cultivating of the vocational basic ability & $\begin{array}{l}\text { Establishing and operating the NCS-based curriculum to } \\
\text { enhance the vocational basic skills }\end{array}$ \\
\hline & Utilization of non-curriculum & $\begin{array}{l}\text { Spreading NCS to the college's curriculum through } \\
\text { non-curriculum areas (lectures, workshops, etc.) rather than } \\
\text { curriculum areas }\end{array}$ \\
\hline & Internship·Field practice & $\begin{array}{l}\text { Establishing and operating the courses of internship or } \\
\text { on-the-job training based on } N C S\end{array}$ \\
\hline \multirow{2}{*}{ Individual-applied } & Subject-application of professor level & $\begin{array}{l}\text { Establishing and operating the NCS-based curriculum by } \\
\text { individual professors with interest }\end{array}$ \\
\hline & Utilization of research meeting/small group & $\begin{array}{l}\text { Seeking and applying the application scheme of } N C S \text { through } \\
\text { a research meeting or a small group between professors }\end{array}$ \\
\hline
\end{tabular}

Note. Source: Lee, Y. (2015).

The department-applied type is applied the NCS-based curriculum to the whole or part of the curriculum of the individual department or major. The employment-supported type is the case that the operating goal and purpose of the NCS-based curriculum are focused on employment. It is developed and operated by the organization of liberal arts education and the employment support organization. The individual-applied type is a way to develop and operate the NCS-based curriculum in level of individual professor's interest, or to develop and operate the NCS-based curriculum after professors organize a research society.

K-University's Business School mainly consists of the type of subject-application based on department, cultivating of the vocational basic ability, and utilization of non-curriculum centered on undergraduate curriculum. In the future, it is desirable to carry out additionally the type of internship field practice if the industry-academia cooperation becomes more widespread.

\section{Development and Operation of NCS-Based Curriculum/Program}

There are significant differences in the curriculum of K-University's Business School and NCS classification system (subdivision, capability unit, and capability unit factor). It is desirable to select the appropriate content from NCS subdivision, ability unit, and capacity unit element focusing on the curriculum of Business School. 
In 4-year universities where most of the theoretical content is available, it is appropriate to use partly NCS in order to improve the practical skills of students. But it is also possible to refer to the theoretical education contents based on the knowledge of NCS. That is, in competency unit of NCS, the knowledge can be applied to theoretical subject and the skills can be applied to the practical subject.

There are the achievement level and the difficulty level of learning ability from Level 1 to 8 at NCS, and it is appropriate to use it as teaching-learning contents only when the level of competency unit and competency unit factor at NCS are four to six in 4-year college. However, it can be used as the basic learning contents even if the level of competency unit and competency unit factor is three or less, and it can be used as the intensive learning contents even if it is seven or more.

The learning module of $N C S$, which is a teaching-learning material that shows detailed contents related to theory and practice so that the competency unit can be utilized in education and training, can be used easily when it is developing and operating a curriculum.

Among the contents of NCS, the contents of environmental analysis and the lifelong development path model of the utilization package can be used for career guidance.

In order to develop and operate a curriculum using NCS at 4-year university, it consists of five stages: preparation $\rightarrow$ diagnosis $\rightarrow$ establishment of execution plan $\rightarrow$ execution (development of curriculum) $\rightarrow$ evaluation. In the execution phase, the development process using NCS is promoted.

The preparation phase constitutes a team of staff and NCS experts, and identifies the needs of university members to what extent and level of NCS-based curriculum.

The diagnosis phase consists of the process of planning, diagnosis, and diagnosis feedback to diagnose the characteristics of the university's organization and department hoping the introduction of NCS

In the establishment of execution plan, based on the needs and the diagnoses obtained at the previous stage, it establishes the specific action plan or schedule according to what is the purpose of introducing NCS, what type of application will be applied, which level of NCS is applied.

The execution phase is to develop the NCS-based curriculum or program according to the established execution plan or schedule. It consists in the order: analyze environment and requirements related to the job/department $\rightarrow$ establish the type and the goal of human resource development $\rightarrow$ define the job and describe the classification system of NCS $\rightarrow$ set up and verify the job model by NCS system $\rightarrow$ analyze and make up a NCS-based course $\rightarrow$ draw up the course profile (lecture plans, etc.) $\rightarrow$ draw up the curriculum roadmap (see Figure 3).

The evaluation stage examines the satisfaction of the school members, the student's academic achievement, and the practical application infield practice on the introduction and operation of the NCS-based curriculum as a result of $N C S$ operation.

\section{Establish the Infrastructure to Operate the NCS-Based Curriculum}

In order to execute the adoption process of NCS-based curriculum, a variety of support and improvement needs to be made within the university.

1. It is desirable to cultivate the staffs' professionalism for operating the NCS-based curriculum (or program), and to form a professional organization for operation and support of NCS.

2. In order to prepare for reorganization and operation of NCS-based curriculum, it is necessary to change the school's rules and to have the facilities and the equipments suitable for operation of the curriculum. 
3. The restructuring of the bachelor's system can be distinguished in preparing the completion system of the NCS-based curriculum and non-curriculum. The completion system of NCS-based curriculum should be designed the bachelor's regulations for the university when it apply NCS as a major or liberal arts curriculum. The completion system of NCS-based non-curriculum should be determined the connection with credit, the evaluation methods, etc., and specified as a regulation in the bachelor's degree system when it apply NCS as a non-curriculum program.

4. It should support the active support for teaching and learning, such as workshops to enhance the understanding of NCS and the support for curriculum development by establishing a support system for teaching and learning. And it should be managed continuously until settlement after introduction of NCS-based curriculum through doing regularly the lecture and the consultation.

5. It is necessary to strengthen the capacities of individual disciplines and department of liberal-education, department of academic and bachelor affairs, and department of employment support, and to establish a collaboration system between departments that operate curriculum.

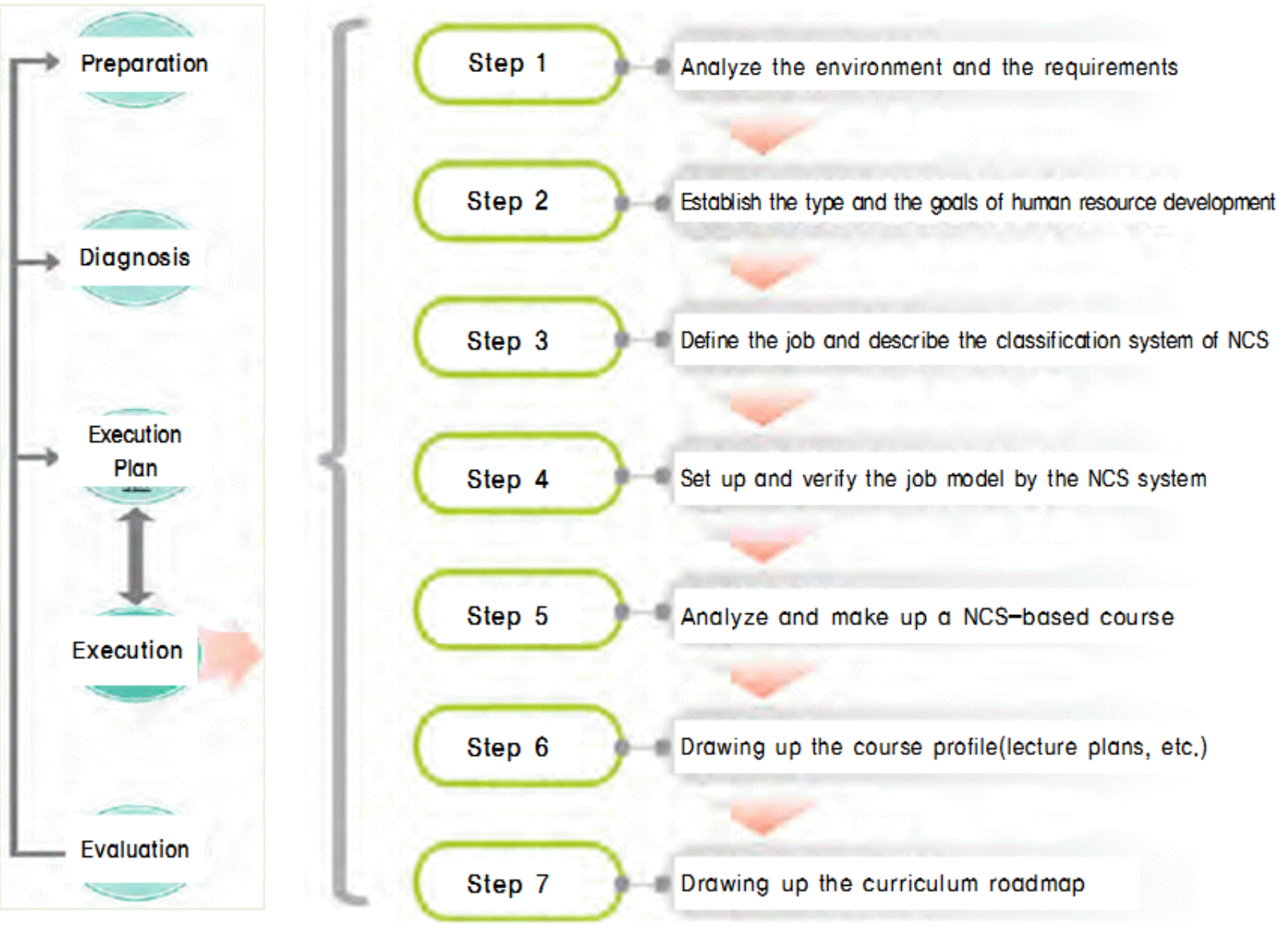

Figure 3. NCS-based curriculum development model of 4-year universities.

\section{Conclusions}

It examined the application method of NCS at 4-year university by base on the development and application system of NCS, the utilization status of NCS, and the comparison of curriculum and NCS system in 4-year universities. 
The implications for future NCS application by base on these findings are as follows:

1. Up to now, there is not the leading model for the use of NCS at 4-year universities, and the application level of NCS at 4-year universities is an introduction step for self-help purposes in a situation that the application process of NCS are not systemized. The definite understanding of NCS, vocational basic capacity, NCS-based curriculum, etc. should be preceded for the members of 4-year universities.

2. It is necessary to develop the curriculum, to operate the baccalaureate, to expand the training facilities and equipment, to switch to the educational methods linked to the field, to support the infrastructure construction at the government level, and to manage the quality of education.

3. The understanding of NCS and NCS-based curriculum should be preceded for 4-year university's members. Therefore, it is necessary to provide the systematic training on the uses of NCS for 4-year university's staff.

4. It is necessary to establish an industry-university cooperation system for the on-the-job training to operate the curriculum (or program) that utilizes NCS or the basic ability. In some of the operational cases, there is not the field linkage for the job education of competency unit required in the curriculum.

5. It is needed a administrative and financial support system for utilizing NCS or the basic ability of 4-year universities. It is needed the support system to provide the government's financial assistance and a systematic consulting service consisted of the NCS expert in order to build the operational infrastructure of NCS.

6. In order to acquire the necessary expertise on NCS, it is necessary to find out and share the use cases of $N C S$ at 4-year universities. Namely, it is desirable to have the learning opportunity to share the information about the application cases of actual fields and to secure the fieldwork by activating the opportunities to share the use cases of NCS.

\section{References}

Bae, S. H. (2016). Quality management strategies and guidelines for data-based education supporting student success: High-effective education programs: What are the educational programs that lead to high student achievement? In The 2nd Symposium on Advancement of Undergraduate Education. Korea: Sungkyunkwan University Education Innovation Center.

Baek, J. M., \& Park, Y. G. (2012). An exploratory study on the possibility of 4-year university's education in NCS. Career Research, 2(2), 1-19.

Human Resources Development Service of Korea. (2015). The competency-oriented recruitment based NCS for employment workers. Seminar Kit.

Kangwon University's School of Management and Accountancy. (2016). Development Plan of Kangwon University's School of Management and Accountancy.

Kim, H. S. (2015). Structural reform of university and utilization of NCS: A case of university lifelong learning center. In Conference Kit, Korea: Korea Vocational Qualifications Association.

Kim, H. Y., \& Lee, S. J. (2013). A study on the use of competency diagnosis test: Focusing on the linkage of the diagnosis tools and the curriculum/compared program. Cultural Education Research, 7(4), 139-172.

Kim, J. S. (2015). Structural reform of university and utilization of NCS: NCS application of 4-year university. In Conference Kit, Korea: Korea Vocational Qualifications Association.

Kim, S. N., Jung, H. J., Lee, M. W., Kim, J. Y., \& Hyun, J. H. (2015). Analysis on the use of NCS learning module. Korea: Korea Research Institute of Vocational Education and Training.

Korea Research Institute of Vocational Education and Training. (2016). Manual of NCS-based Learning Module.

Lee, S., Seo, Y. H., Chang, S. E., \& Jeong, D. Y. (2014). A case study on the operation of curriculum based on national competency standards in foreign countries-Focused on UK and Australia. Korea: Korea Research Institute of Vocational Education and Training. 
Lee, Y. M. (2015). A case study of 4-year universities by the application type of NCS. Korea: Korea Association for the Education Study.

Lim, S. K. (2015). The lifelong learning-centered university and the application case of NCS. In Conference Kit, Korea: Korea Vocational Qualifications Association.

Ministry of Education \& Ministry of Employment and Labor. (2014). How to create a competency-centered society. Press release. Ministry of Employment and Labor. (2015). 2015 Guide for the competency-centered recruitment based NCS.

Park, D. Y. (2013). A study on the current status and tasks of capacity education using National Competency Standards (NCS). The HRD Review, 16(3), 52-71.

Park, J. H. (2015). Structural reform of 4-year universities and utilization of NCS: Utilization of NCS and characterization case in the local universities. In Conference Kit, Korea: Korea Vocational Qualifications Association. 